\title{
Viticultural Landscape Patterns - Embedding contemporary wineries into the landscape site
}

\author{
Olga Harea, Anna Eplényi PhD, Szent István University, Hungary
}

\begin{abstract}
In the recent years, the wine culture, being mostly influenced by economic conditions, undergoing some transformations and moving more into the sphere of relaxation, and entertainment. Parallel with the development of the wine culture, the wine architecture also undergoing changes - they had not only to accommodate to the production but also to represent the firm, and being the part of the new brand. Nowadays, to fit into the landscape, to preserve and express its character as well as the tradition and the mystery of wine production is the basic evaluation criteria for wine architecture.

The main focus of the research is to emphasize how to fit the architectural forms into viticultural landscapes. To carry out the study, were selected six examples of comtemporary wine arhitecture, which are located in a specially valuated and protected cultural landscape. The samples are analysed from two aspects: the context (the relevance to the landscape patterns / courtyard scale, connection with the terrain) and basic visual elements (materials, roof shape, form-imitation, view spots). The goal is to emphasize the techniques and strategies for the improvement of wine architecture and landscape, and provide an understanding about the current state of built forms and landscape design in vineyards.
\end{abstract}

Keywords: viticultural landscapes, vineyard patterns, wine architecture, vineyards

Introduction - Looking back

Viticultural landscapes are a perfect example of the most beautiful human-made landscape settings in the world. In Mediterranean and temperate climate regions, vineyards cover mountainous, hilly, coastal and floodplain areas. They represent one of the largest agro-ecosystem, and they are the most important agricultural activity in terms of environmental impact and income [1].

Vineyards have enriched the landscape since time immemorial. They give countries their characteristics and order. Their geometric patterns and colourful varieties are a magical element of expressive landscapes [2], which prove how the utilitarian organization of the land can also be aesthetically pleasing.

Ever since humans first discovered how to turn grapes into a delicious, intoxicating beverage, there have been special buildings for wine production. Although the ancient Greeks are considered to be the founders of viniculture in the Mediterranean, it was the Romans who, as well as fostering the extensive expansion of vineyards in their empire, erected purpose-built, free-standing buildings for viniculture from the first century AD onwards [3].

During the last decades, the culture of wine has been redefining itself and wineries architecture has undergone transformations that have been a consequence of this evolution. Firstly, there were Roman farming estates - villa rustica and villa urbana [3], various underground areas and cellars to provide a stable temperature for the production and storage of wine. Later, fortresses, castles, monasteries, church institutions and hospitals, palaces and chateaux were built above wine cellars, where the wine was also consumed.

A significant step in the development of winery architecture occurred mainly from the 19th century. In the wake of the Industrial Revolution, champagne and sparkling wine cellars (in Champagne), Sherry bodegas (in Andalusia) and port wine lodges (in the Douro Valley in Portugal), riding a wave of worldwide export success, stepped up their business activities. This increase in production created a need for new buildings of unprecedented dimensions [3]. Consequently, while wine estates and cellars were undergoing a structural redesign, the winemaking process and the rural character of wine-growing slowly began to change.

In the 20th century, directly after the Second World War, wine architecture in most of European wine-growing countries saw little in the way of revival. This only emerged from 1980 onwards [3]. The architecture of wine progressed rapidly and stridently, at the same time undergoing some dramatic transformations [4] - focused on a comprehensive modernization of production facilities and buildings [3] (e.g. Château Lafite Rothschild (1987), Château Pichon Longueville (1990) etc.). As a result, the new structures, in which functionality was the top priority, were massive and flashy and did not always fit harmoniously into their surroundings or regional landscape. 


\section{Contemporary Wine Architecture}

In the recent years, the wine culture, being mostly influenced by economic conditions, is experiencing again some transformations and moving more into the sphere of relaxation, and entertainment. The wine architecture has reshaped its face, losing the traditional historical and rural features to add more agricultural, business and bran-making one.

Visual considerations are becoming more vital to a winery's image and status [3]. To design new wineries or extensions was important to respect a number of standards, such as to make them appropriately blend into the landscape, respect the topography of the terrain and genius loci of the site where the structure is located, to express its character as well as the tradition and the mystery of wine production.

The architects are being challenged to rethink the winery as a bold contemporary expression of tradition and innovation, agriculture and technology, production and hospitality [5]. As a result, many new wineries and vineyards have captured the public's eye in recent years thanks to their unique functional architecture, which perfectly transmits the atmosphere of their surroundings while reflecting the tradition of the winemaker. Some of these buildings are designed to establish brand identity and excite public attention in a fiercely competitive market, others blend into the landscape or abstract the local vernacular [5]. The content of wineries has been changed, alongside the physical requirements of a winery - the fermenting cellar, wine storage area, bottle warehouse, packaging and shipping - certain of these buildings include tasting area, shop, restaurant and even accommodation. Such buildings are typically situated alone and surrounded by vineyards, and offer to wine lovers the privilege of experiencing the exceptional ambiance and landscape vineyards. Therefore, they do not serve only for collecting and producing, but also for "selling" the landscape [6].

\section{Goals and objectives}

The most important communication for architectonic development is how the countryside can be built on, now and in the future, and how a new understanding of symbiosis of nature and culture could be created [7].

The particular focus of the research is to emphasize how to fit the architectural forms into viticultural landscapes. Based on case studies the aim of this paper is to answer the following questions: What kind of techniques do the designers use to fit the building into the landscape? How does the landscape character influence the building?

The case study analysis of winery and vineyard sites provides a richer understanding about the current state of buildings and landscape design in vineyards and offers design guidance and strategies for the improvement of wine architecture and landscape.

\section{Evaluating method}

Relying on personal interpretation, we have selected six examples (new buildings and extensions), which show a complex relation to the landscape, and are award winning projects, widely published on websites, in periodicals and books. As a consequence we assumed that our projects represent top quality architecture, and at the same time they may also work as a model.

To carry out the study and get a qualitative result, we relied on written materials (designers' texts, architectural critics' reviews), photos, and layout plans from Google Maps. To dissect and observe contemporary design strategies of the case studies we examined their context: site plan - the relevance to the landscape patterns / courtyard scale; connection with the terrain: the various degree of cut and fill, sunken spaces; and basic visual elements: materials - colour / texture; roof shape / form-imitation; view spots: glass and terrace / balcony surfaces). All the schemes were shaped in "Adobe Photoshop CS6" program, using some graphical tools were marked/emphasized the particular features, such as layout of the building, entrances, patterns, landforms, etc.

\section{Discussion}

The case study buildings are situated in a specially valuated and protected cultural landscape. The Quinta Do Vallado Winery is established in Baixo Corgo wine sub-region of the Douro Valley region (a UNESCO World Heritage Cultural Landscape Site since 2001), Portugal. The Franz Keller Winery is settled in the Baden wine region, namely in the Kaiserstuhl wine district, Germany. The Antinori Winery is located in Chianti, wine district of Tuscany, Italy. F.X. Pichler Winery is located in Wachau, wine district of Lower Austria (UNESCO World Heritage site since 2000). The Swiss example, Lavaux Vinorama is established in Lavaux sub-region of Vaud wine region (a UNESCO World Heritage Cultural Landscape Site since 2007). The Ysios Winery is located in Laguardia, in the Rioja Alavesa region, Spain.

Quinta do Vallado, founded in 1716, is one of the first port houses in the Douro Valley. The wine estate, consisting of 130 ha of vineyards, lies on both banks of the Corgo River, a tributary of the Douro River. In 2003 the Quinta do Vallado Douro Reserva received its first prizes, afterwards the wine estate became one of the most highly regarded in Europe and can now look back on a number of international 


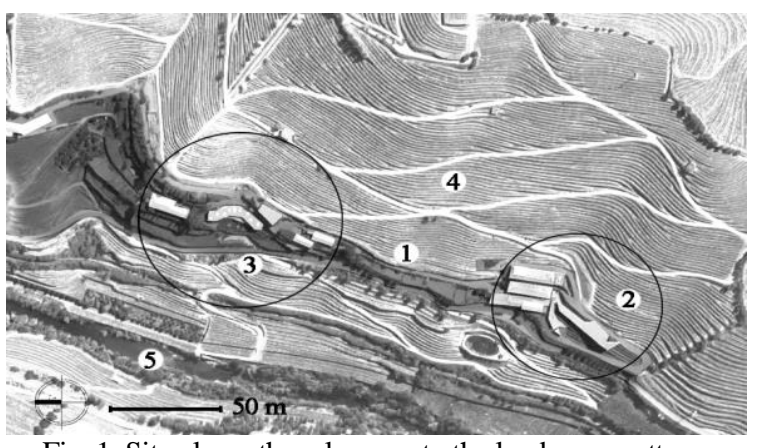

Fig. 1. Site plan - the relevance to the landscape pattern: 1. built area; 2. production zone; 3 . leisure zone; 4. terraced vineyards; 5 . Corgo River [Source: created by author, 2017]

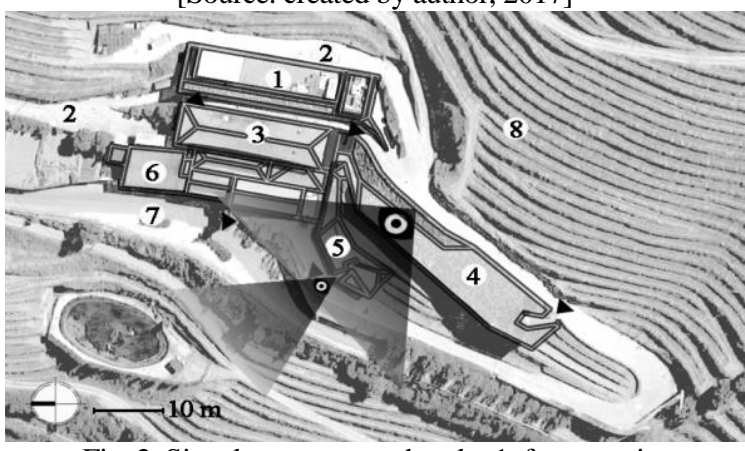

Fig. 2. Site plan - courtyard scale: 1 . fermentation warehouse; 2 . production area/service road; 3 . old winery;

4. hogshead warehouse; 5. reception / visitors entrance;

6. ancillary buildings; 7. visitors / residents parking area / road / entrance; 8 . terraced vineyard [Source: created by author, 2017]

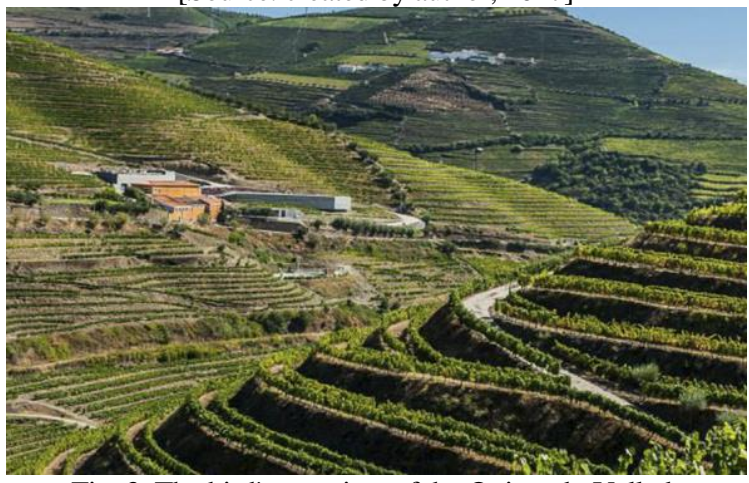

Fig. 3. The bird's eye view of the Quinta do Vallado [Source: https://www.facebook.com/quintadovallado/ (Accessed 19, April 2017)]

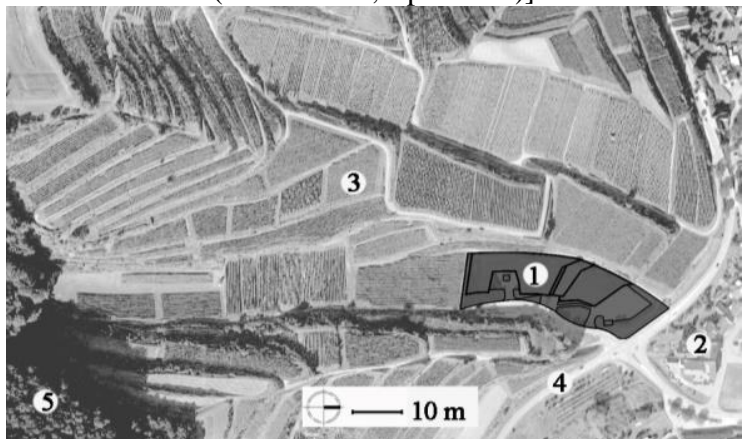

Fig. 4. Site plan - the relevance to the landscape pattern: 1. built area; 2. Oberbergen town; 3 . terraced vineyards; 4. Bergstrasse - route of mountains, wine, and castles; 5. Black Forest [Source: created by author, 2017] awards. This recognition increased demand for the wines, so in 2006 , the proprietors were already thinking about extending the estate [3]. The expansion project included two areas of intervention - production and leisure - completed in 2010 and 2012 by Guedes + de Campos Architects.

"According to the architect, the project was supposed to "ideally blend into the natural landscape and not look too bulky and heavy". For Vieira de Campos, there were two key aspects: making use of traditional regional building materials, and emphasizing the building's relationship to the surrounding landscape" [3].

The estate's vineyards, shaped by the meandering water plan of the river, are planted on the steep hillsides and are divided in elegant patterns, which are characterized by smooth and curved edges. Most of the vines are planted in horizontal, continuous rows, on handbuilt stone terraces or bulldozed earth terraces, and some on unterraced plots. The vines' rows follow the ground lines and are bordered by olive trees and punctuated by the Italian-cypress. The built area is set in a dominant and strategic position taking advantage of the network of curved pathways (Fig. 1). The new volumes of winery - Fermentation Warehouse, Hogshead Warehouse and Reception - create a relation of tension and balance between old buildings and topography, merging in the land declaring its artificial nature. The entire production area is organized in terraces, supported by retaining walls of schist and granite, the staircases and balustrades. The silver-grey structures, coated with local burnt shale worked in a contemporary way, imitate the natural form of the slope. The Fermentation Warehouse has parallelepiped layout and is embedded in the ground. The Hogshead Warehouse and Reception represent a big encrusted mass in the field and ends in a cantilevered beam. The linear shape of the building stretches along the layers, while it is also partially embedded in the ground. All the guest entrances and passageways offer friendly decors and amazing views (Fig. 2, 3).

Franz Keller Winery (2013, architects: Geis and Brandtner), with its 57 hectares of vineyards, lies at the foot of the Badberg (nature reserve), in a blind valley of the Kaiserstuhl mountains. The estate is best known for producing dry wines reflecting the extraordinary terroir of the Kaiserstuhl and these wines have found international recognition as outstanding ambassadors for Baden's wine culture.

"The new Franz Keller winery is a very clear illustration of how everything to do with wine is changing in Central Europe. [...] If the natural surroundings are taken into account and the processes of harvesting, storing, pressing and again storing are logically incorporated into the plans, the result will be successful structure such as the "invisible" terraces of Oberbergen" [4]. 


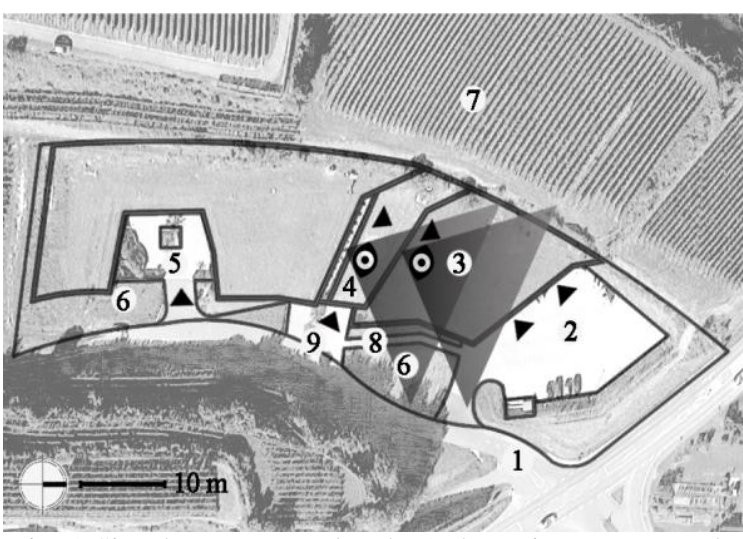

Fig. 5. Site plan - courtyard scale: 1 . the main entrance on the winery's territory; 2 . visitors/residents parking area/ entrance for employees; 3-4. terraces/exits;

5. multifunctional yard; 6 . green surfaces; 7 . Vineyard;

8-9. stairway leading to the entrance for visitors/entrance

[Source: created by author, 2017]

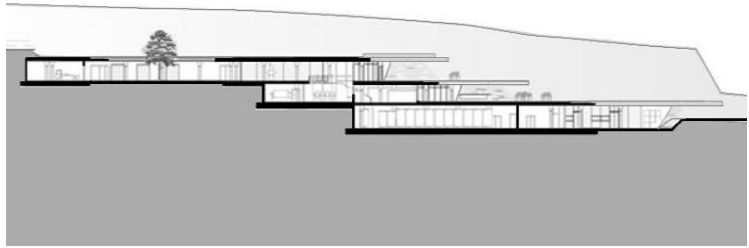

Fig. 6. Longitudinal section of the winery [Source: https://www.beton.org/inspiration/ (Accessed 19, April 2017)]

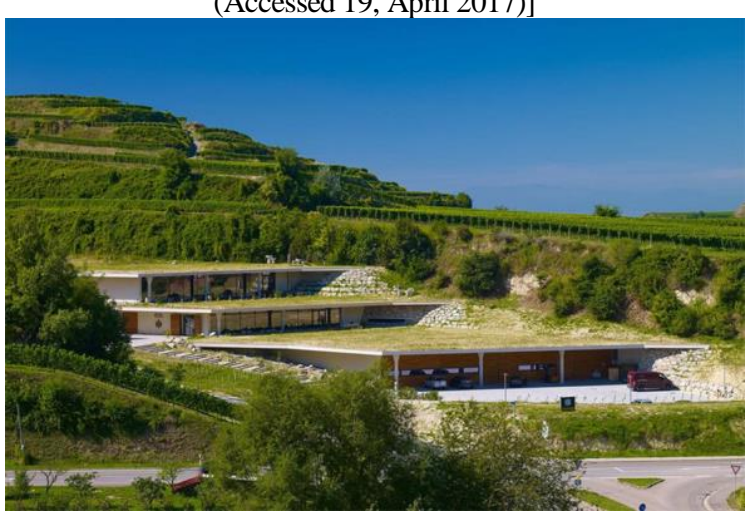

Fig. 7. The "terraced building"

[Source: https://www.beton.org/inspiration/

(Accessed 19, April 2017)

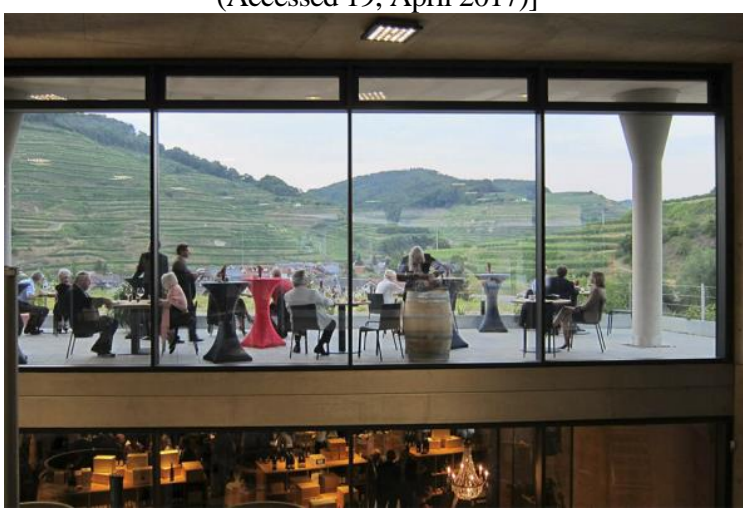

Fig. 8. The view towards landscape

[Source: https://www.facebook.com/

FranzKellerSA/photos (Accessed 19, April 2017)]
The estate's vineyards, shaped by the Black Forest, volcanic hills, small town of Vogtsburg-Oberbergen and roads, are grown on terraces and steep slopes that follow the contours of the old volcanic cones. This productive land is divided in dynamic, irregular patterns characterized by the rows of vines with different orientations (Fig. 4). The building footprint, almost invisible above ground, was shaped by the adjacent plots. The building seems to be the continuation of the terraced vineyard levels, it extends towards the settlement but does not reach it (Fig. 5). The terraced building is partly sunk into the ground and covers three levels, where each step in the wine process strategically takes place on a specific floor (Fig. 6). Surrounded by the well-harmonized green environment, it is an expert mix of natural and sustainable materials such as glass, stone and wood (Fig, 7). Its green terraced roof follows the shape of the hill and is covered with a layer of soil up to four meters and planted with grassy seeds from neighboring Badberg nature reserve. The reinforced concrete structure, the tapered columns and the huge windows make the building open and communicative both inside and outside. The interior provides interesting insight into the production processes and a unique panoramic view from the terraces (Fig. 8).

Antinori Winery (2012, Arch: Archea Associati) is located within vineyards in the rolling landscape of the hills of the Chianti region, on the road between Siena and Florence. In 2015 it received the European Union Prize for Contemporary Architecture - Mies Van Der Rohe Award.

"The physical and intellectual construction of the winery pivots on the profound and deep-rooted ties with the land, a relationship which is so intense and suffered as to make the architectural image conceal itself and blend into it," says Archea Associati [8].

The estate's vineyards, shaped by the hills studded by cypresses, forests, roads and a small town, are grown on gently undulating hills. The land is divided in irregular, sinuous patterns (Fig. 9). The industrial complex's body, built almost completely underground and shaped by the adjacent roads, extends horizontally along the natural slope, paced by the rows of vines which, along with the earth, form its "roof cover" (Fig. 10). "The invisible building", divided into two floors with different levels (Fig. 11), is designed in earthy colours and marked by two horizontal cuts that follow the curves of the hilly land. The first cut is closed by large glazed fronts, while the second, upper one, is closed by walls and gates in Corten steel. The used materials, Corten steel, red facing bricks, oak and glass, perfectly harmonize with the natural charm of the surrounding countryside. The structure 


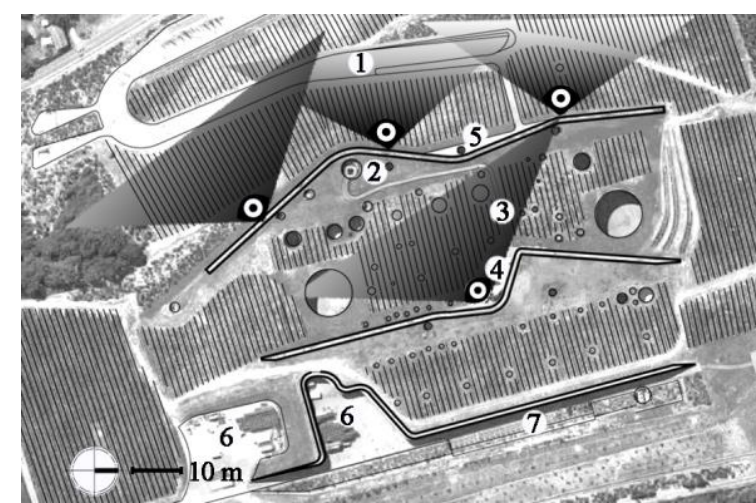

Fig. 10. Site plan - courtyard scale: 1 . main entrance on the winery's territory; 2 . spiral staircase, which ascends from the underground parking to the balcony; 3 . vineyard;

4. terrace /gates; 5 . panoramic terrace/exits 6. multifunctional yards - production/ transportation facilities;

7. parking area for employees [Source: created by author]

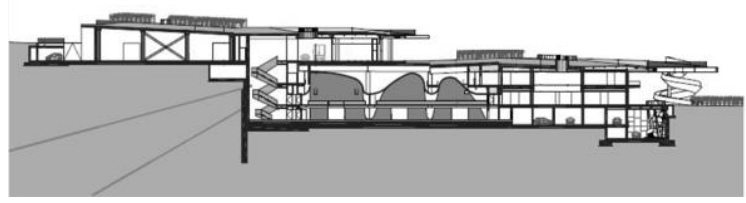

Fig. 11. Cross-sectional view

[Source: http://www.promozioneacciaio.it (Accessed 19, April 2017)]

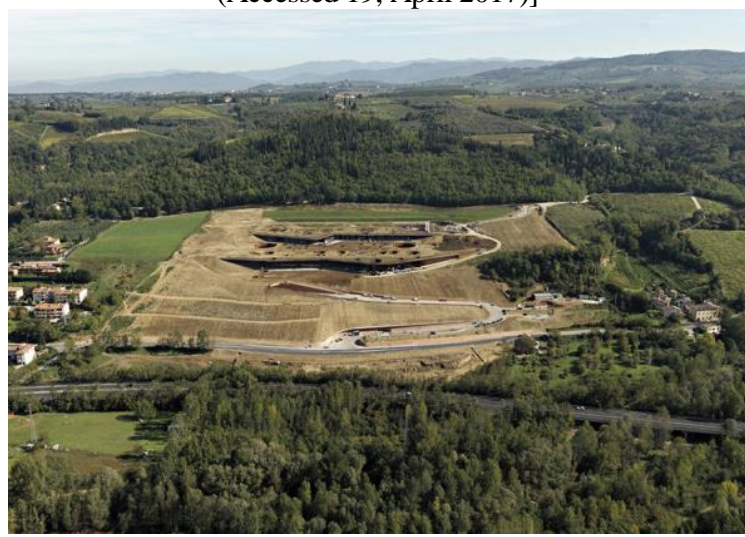

Fig. 12. The bird's eye view of the "invisible building" [Source: http://www.archdaily.com (Accessed 19, April 2017)

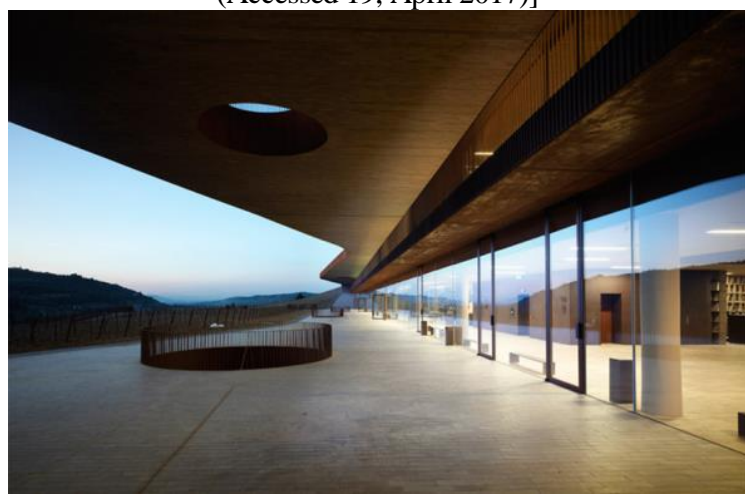

Fig. 13. The first cut - the panoramic terrace shaded by the roof [Source: http://www.designboom.com (Accessed 19, April 2017)] has a green stepped roof, completely covered by vineyards, and is pierced by a couple of brown, circular openings, which bring the light into the depths of it. One void contains a large spiral staircase, which ascends from the underground parking to the balcony on the vines (Fig. 12). The volume opens to the landscape through the first cut, which is visible from the exterior and leads to the spacious panoramic terrace shaded by the roof, offering to the visitors a panoramic view of the surrounding landscape (Fig. 13).

FX. Pichler Winery (2009, Arch: Thomas Tauber), one of the icons of Austrian winemaking and viticulture, is situated in the Wachau Valley, between the hillside vineyards of Loiben, the ruins of Dürnstein castle and the Danube River.

"The long, flat-roofed building is in no way showy; it is not even located on the main road, but tucked away behind an old vintner's house, leaving the landscape of the Wachau undisturbed" [3].

The winery's vineyards, comprising 18 hectares, are concentrated on the southern side of the Danube and are planted in steep terraces and slopes, originating from the 13th century. Shaped by the river, settlements, forested hills and roads, the productive land is divided in geometric, regular patterns (Fig. 14). The parallel rows of grapes guide the shape of the parking lot to the footprint of the building (Fig. 15). Situated on a flat terrain, the two-storey prism is faced with dark grey and anthracite-coloured concrete panels. The handground and sanded concrete with inclusions of a green stone give result of rough heterogeneous surface, which is reminiscent of the traditional stone walls that are so typical of this region. On the main facade a contrasting band of aluminium laths rises up from the ground and optically connects the glass section of the building (Fig. 16). The curved, wave-like aluminum appliqué reflects the Danube River, which lies beside it. On the other side, a generous glass facade, covering customer area, reflects the vines and offers a panoramic vista of the vineyards and surrounding landscape (Fig. 17).

The Lavaux Vinorama (2010, Arch: FournierMaccagnan) was built as a "teaching and social centre" [3] on the most stunning vineyard landscape. The project won the 2013 Architizer A+ Jury Award in the bars \& nightlife category.

The site is characterized by the terraced vineyard, the lake and the stream running from the Forestay River - offering a division of the land as well as unique structural element (Fig. 18). Compared to the earlier examples this project misses the production facilities of an usual winery, it focuses on wine tasting and selling. The building has a monolithic cube nestled like a fortress into the steep slopes, emulating the rocky cliff where grape vines enjoy the warm and moisture-laden air. 


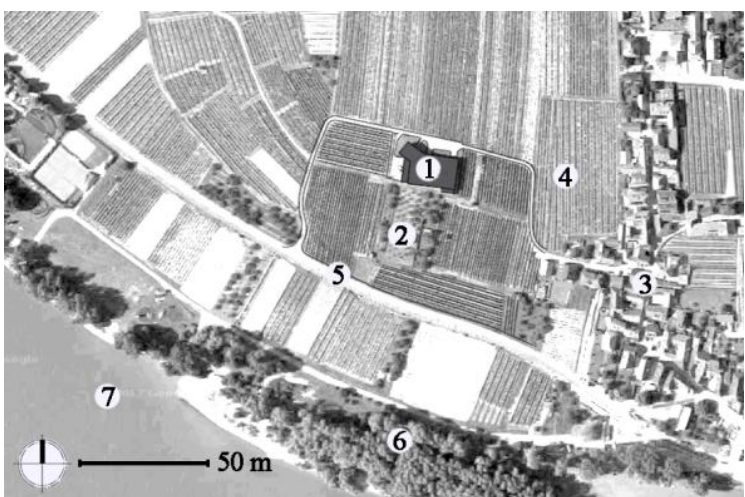

Fig. 14. Site plan - the relevance to the landscape pattern: 1. built area; 2 . orchard; 3 . Oberloiben town; 4. vineyard;

5. Danube Federal road 3; 6. green mass; 7 Danube River [Source: created by author, 2017]

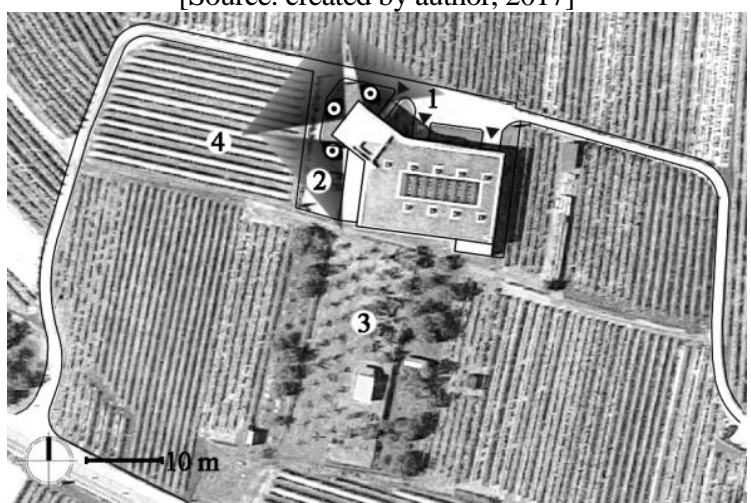

Fig. 15. Site plan - courtyard scale: 1. entrances / parking area for visitors / employees; 2. multifunctional yards; 3. orchard; 4. vineyard [Source: created by author, 2017]

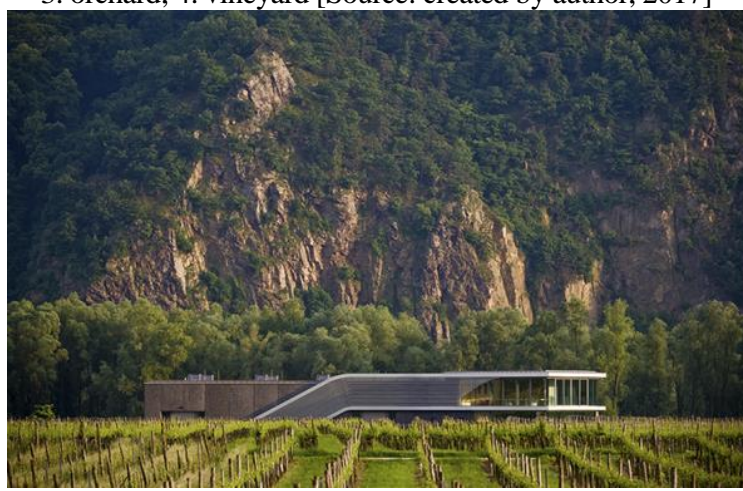

Fig. 16. FX.Pichler Winery [Source: http://www.loxpix.com/ spaces/winery (Accessed 19, April 2017)]

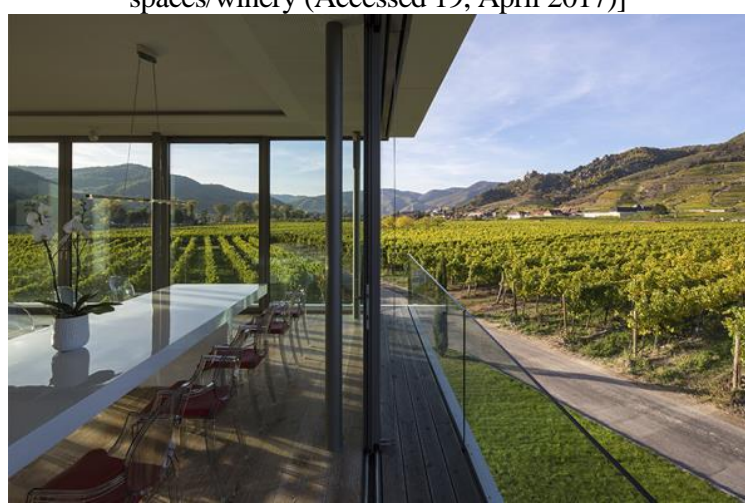

Fig. 17. The panoramic view from customer area [Source: http://www.loxpix.com/spaces/winery (Accessed 19, April 2017)]

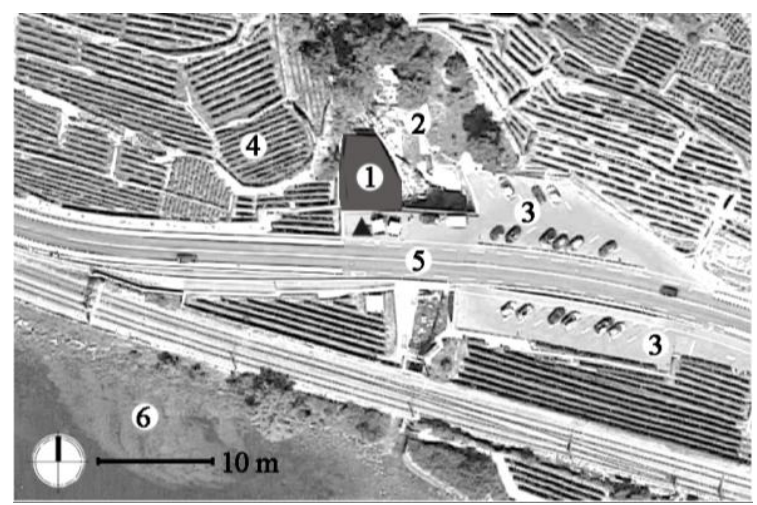

Fig. 18. Site plan - the relevance to the landscape pattern:

1. built area; 2. Forestay cascade; 3. parking area for visitors / employees; 4. vineyard; 5. lake road; 6. Lake Geneva

[Source: created by author, 2017]

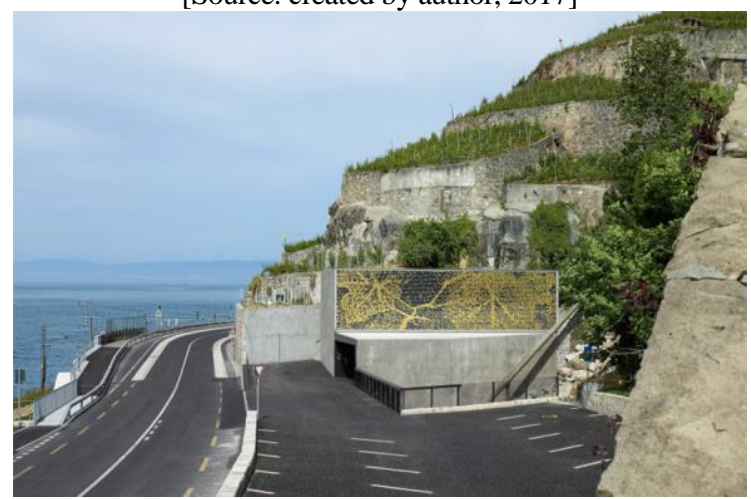

Fig. 19. Lavaux Vinorama

[Source: http://www.lavaux-vinorama.ch/fr/N355/levinorama-en-images.html (Accessed 19, April 2017)]

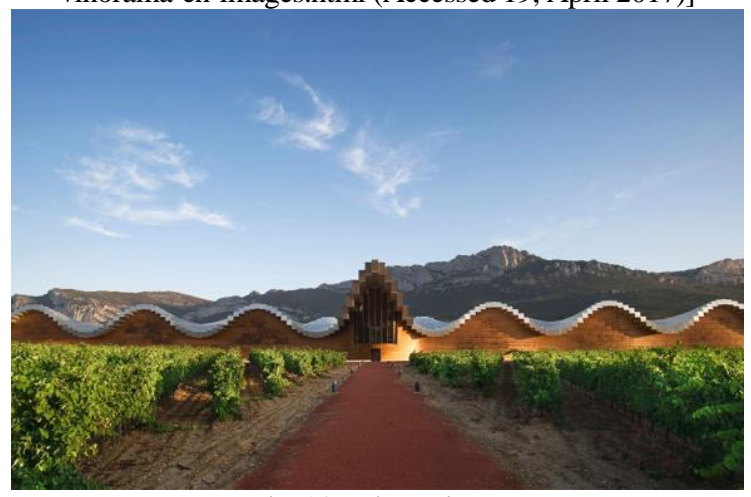

Fig. 20 Ysios Winery

[Source: http://buildipedia.com (Accessed 19, April 2017)]

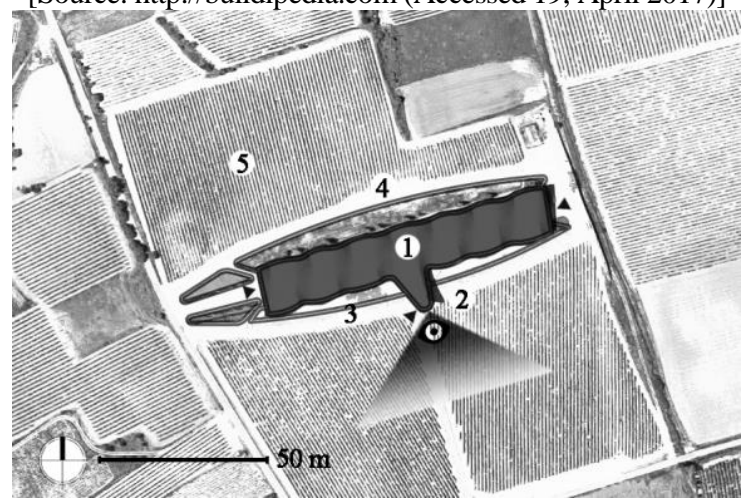

Fig. 21. Site plan - courtyard scale: 1 . built area;

2. main entrance; 3.pool; 4. parking lot / green area; 5. vineyard [Source: created by author, 2017] 
The facade is covered by a sculptural steel rainscreen, designed by Swiss artist Daniel Schleapfer (Fig. 19). Its pixelated surface depicts grapevines, which impart a dappled light to the interior tasting rooms. From here the cascade, vineyards and lake are visible - the only place in the structure from where these may be viewed.

The jurors appraised the architects strive to fit into the historic and natural context. ,,They chose to build with concrete - a material both historic and modern, used by the ancient Romans and Swiss modernists. To pay further homage to local building traditions, the concrete was composed of local sand and aggregate, physically including the earth of the site into the structure" [9].

Ysios Winery [5] (2001, Arch: Santiago Calatrava), pixelated-looking landmark, is located at the foot of the Sierra de Cantabria mountain range, in the Rioja Alavesa region.

The vineyards of Ysios winery, shaped by mountain range and roads, comprise 75 hectares and are grown on the terraces and gentle slopes. The site is divided in dynamic, irregular patterns characterized by the vine's rows with different orientation. The rectangular structure, situated on a flat terrain, represents a ruled surface wave, which combines concave and convex surfaces as it evolves along the longitudinal axis. The body of the building is made out of copper stained cedar boards - bearing resemblance to that of giant wine barrels - precast concrete panels and fret aluminum plates. The wavy roof follows the silhouette of the surrounding mountain range and is made of gigantic, aluminum bars (Fig. 20). From a bird's-eye perspective, the bars of the roof seems to be guided by the orientation of the vine's rows from adjacent patterns or vice versa (Fig. 21). In the middle of the building, the roof pitches steeply upwards and extends far forward, forming a giant glass-paneled balcony. This raised center marks the entrance to the winery and offers to the visitors a majestic view inside of the winery as well as out over the vineyards. At the foot of the building stretch two lateral pools, lined with white ceramic tiles create a mirror-like reflection.

\section{Conclusions}

Site

The rhythm and geometries of the agricultural landscape patterns influenced and shaped the architecture of the Lavaux Vinorama, Quinta do Vallado, Franz Keller and Antinori wineries. In their design the unique site characteristics were considered, such as natural topography, natural contours of the site, terrain-modelling, the local setting, scenic vistas etc. The built forms are located in the least environmentally sensitive location, thereby minimizing their impacts on natural terrain of the project site.

Connection with the terrain

There are fundamentally different approaches among vineyards regarding construction on the level or on a slope. The Lavaux Vinorama, Quinta do Vallado, Franz Keller and Antinori wineries prove that the concept of a winery embedded in a slope is the most convenient, not only for the production process, which utilizes the gravity, but also for achieving a harmony between site and architecture.

\section{Basic visual elements - Materials}

To mitigate the visual impacts of building mass and to fit it into the natural scenography/local settings, beside the relevance to the landscape patterns and connection with the terrain, the use of materials also play a leading role. In the case of Quinta do Vallado, the use of local materials, such as schist, granite and burnt shale worked in a contemporary way, made the volume blend in with the predominant colours of the surrounding landscape. Designed in earthy colours and made of natural, sustainable materials such as glass, stone, wood, corten steel, bricks, the Franz Keller and Antinori wineries are perfectly fit into the fascinating surroundings. In the case of FX.Pichler, Lavaux Vinorama and Ysios wineries the structure design and materials are visually sophisticated and has symbolic reference to the site. The used materials for FX.Pichler and Ysios wineries provide strong, natural accents and mimic the rocks of the mountains behind them.

Basic visual elements - Roof shape

The green terraced roof of the Franz Keller and Antinori wineries follow the shape of the hills and blend in with the predominant colours of the surrounding landscape. The shape and colour of the Ysios winery has a metaphoric/symbolic reference to the site. The wavy form of the roof recalling large barrels lying side by side and connected by a band of silver, and at the same time it follows the silhouette of the surrounding mountain range. Basic visual elements - View spots

As was mentioned above, the new wineries do not serve only for collecting and producing, but also for "selling" the landscape. All the examples comprise the view spots, which offer to the visitors a view over the vineyards, with the exception of the Franz Keller and Antinori wineries. The terraced buildings are marked by huge glazed fronts, which make them open and communicative both inside and outside, providing a unique panoramic view.

This short study underlines, that architecture can be viewed in greater context, especially if there is a strong need to observe the surrounding landscape. There seems to be a tendency to harmonize architectural composition within the landscape characters and patterns. Wine-design discovered how to use landscape as a brand-making factor, where not only the view from the terraces is crucial, but the view on the whole intervention within the agricultural landscape. The tendency is clear: more-and-more care is taken on toning architecture to the factors of landscape. 


\section{References}

1. Tarolli, P., Sofia, G., Calligaro, S., Prosdocimi, M., Preti, F., Fontana, G.D. Vineyards in terraced landscapes: new opportunities from lidar data. Land Degradation \& Development, 2015, No. 26, pp. 92-102.

2. Architecture and Wine in Central Europe = Architektur und Wein in Mitteleuropa. [ed. Dan Merta] Praha: Galerie Jaroslava Fragnera \& Architectura, 2013, pp. 9, 20.

3. Woschek, H.-G., Duhme, D., Friederichs, K. Wine and Architecture. Munich: Edition Detail, 2012, pp. 10, 16, 18, $19,45,123,125$.

4. Meyhöfer, D., Frahm, K. The Architecture of Wine. Stuttgart: AVEdition, 2015, pp. 14, 114

5. Webb, M., Pfeiffer, E. Adventurous Wine Architecture. Mulgrave: The Images Publishing Group, 2005, pp. 6, 10.

6. Simon, M., Harea, O. Terraced Vineyards - Architectural Responses. 4D Journal of Landscape Architecture and Garden Art, 2017, No. 44 (in press).

7. Meyhöfer, D., Gollnek, O., Hubschmid, P. C. The Architecture of Wine = Die Architektur des Weines = L'architecture du Vin. Corte Madera CA: Gingko Press, 2000, p. 23.

8. Antinori Winery, 11, February 2017, [online 19.04.2017] https://en.wikiarquitectura.com/building/ antinori-winery/

9. Tucked Into A Cliffside, A Swiss Winery Preserves The Landscape-And Wows Guests, 5. April 2013, [online 19.04.2017] http://architizer.com/blog/tucked-into-a-cliffside-a-swiss-winery-preserves-landscape -and-wows-guests/

INFORMATION ABOUT THE AUTHORS:

Olga Harea MSc. Architect. Graduated Technical University of Moldova, Faculty of Architecture and Urban Planning. PhD student at Szent István University, Faculty of Landscape Architecture. In the PhD research she focuses on the contemporary architecture and their forms of fitting into local landscape character, especially in the wineries topic. E-mail: hareaolga@gmail.com

Anna Eplényi PhD. MSc. Landscape Architect and BA. Art-teacher, leader of Children Art Studio Foundation (www.gyikmuhely.hu). Since 2015 Senior Lecturer at the Dept. of Garden Art and Garden Techniques at the Szent István University (Budapest) teaching various creative topics (drawing, sketching, modelling, garden art). E-mail: eplenyi.anna@tajk.szie.hu

Kopsavilkums. Pēdējos gados vīna ražošanas kultūru aizvien vairāk ietekmē ekonomiskie apstākḷi, tai pārdzīvojot pārmaiņas, un vīna ražošanu aizvien vairāk saistot ar atpūtu un izklaidi. Paralēli vīna ražošanai attīstās arī vīna kultūru reprezentējoša ēku formveide un dizains, kas veido svarīgu aspektu vīna firmu zīmola atpazīstamībai. Tam pamatā ir viens no galvenajiem kritērijiem mūsdienu vīna kultūras attīstībā - arhitektūras formveides un modernisma stilistikas meklējumi ainavtelpā, saglabājot vīna ražošanas tradīcijas un noslēpumus.

Pētījumam ir izvēlētas sešas vīna ražotnes, kas atrodas īpaši aizsargātā kultūrainavā, aplūkojot divus galvenos aspektus: konteksts (atbilstība ainavtelpai, formveides kopsaskaņa ar reljefu, skatu punkti) un arhitektūras formu dizaina detālie elementi (materiāli, jumta forma, formas imitācija). Pētījuma secinājumi liecina, ka trīs no aplūkotajām vīna darītavām - Lavaux Vinorama, Quinta do Vallado, Franz Keller and Antinori - arhitektūras kompozicionālajā valodā ir spēcīgi ietekmējušās no vīna dārzu ritma un geometrijas. Būtiski, ka šo vīna darītavu arhitektūrā ir ņemti vērā unikālas dabas pamatnes īpašības reljefs, ainavas robežas, esošas būves, gleznainie skati, utt. Jaunie arhitektūras elementi ir izvietoti vismazāk vizuāli konfliktējošajās vietās, tādējādi mazinot to ietekmi uz kultūrainavu. Mūsdienīgi risināti ir vīna darītavu Franz Keller un Antinori zaḷie jumti, kas atkārto kalnu formas un kolorītu. 